\title{
Evaluation of some Liver Function Tests During Different Gestational Period
}

\author{
Ahmed H. Al-Hamdani \\ Department of Medical Physiology \\ College of Medicine \\ University of Mosul
}

(Received 21/8/2011;Accepted 26/9/2011)

\begin{abstract}
This study was designed to assess the effect of pregnancy on liver function tests (LFTs) and to identify the variations between these LFTs during different gestational period. The present study include seven parameters: serum liver enzymes (AST, ALT, ALP, AST/ALT ratio) and bilirubin (total, direct and indirect) had been measured in blood of 50 healthy nonpregnant women, their age was ranged between (17-40) years as a control group and in 150 apparently healthy pregnant women their aged between (16-41) years. Pregnant women were divided into three subgroups according to their gestational period: $1^{\text {st }}, 2^{\text {nd }}$ and $3^{\text {rd }}$ trimesters (50 pregnant for each trimester of pregnancy). The results recorded a non significant difference in AST activity in all trimesters compared with control group, while serum ALT activity showed a significant reduction during pregnancy trimesters as compared with control group. The serum ALP activity show a significant increase as gestational period progress. However, the result of AST/ALT ratio showed no significant difference with the increase in the gestational period. Finally, serum total, direct and indirect bilirubin were all non significantly difference in all trimesters when compared with control (except the significant decrease in the comparison of total bilirubin in the $3^{\text {rd }}$ trimester with control group).
\end{abstract}

Keywords: Pregnancy and liver function tests.

\section{فيم لبضن فحومالت ولالف الكبد خلا فترل مختلفة من الحل}

\section{الملهص}

قم تصميم هذا البهث لقيم تأثير الحمل في فحوصك وظافف الكبد وكذلك معرفة التغيرات في هـ ـذه الفحوصات خلل فترات الحمل . تضمنت هذه الدرلسة قيلسسبعة متغيرات متعلقة بوظائف الكبد وهي فعالية

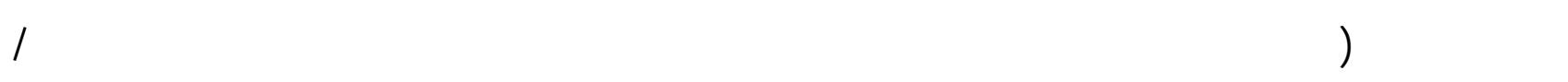

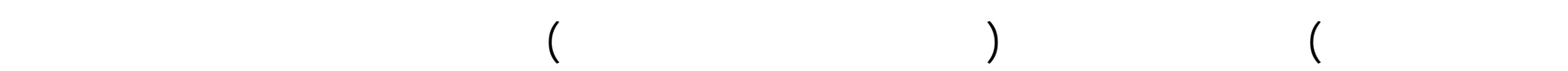

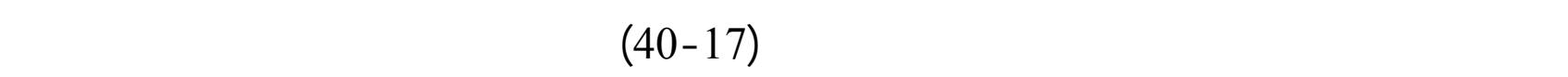


مائة وخمسون من النساء الحوالمل الصحيحك واللاتي تراومت أعمارهن بين (16 -41)سنة. وقم ت صنيف

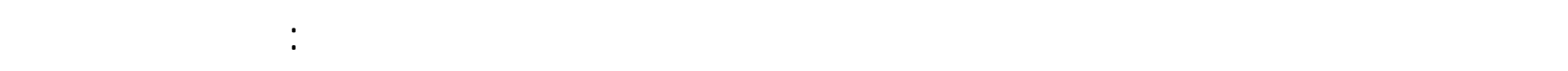

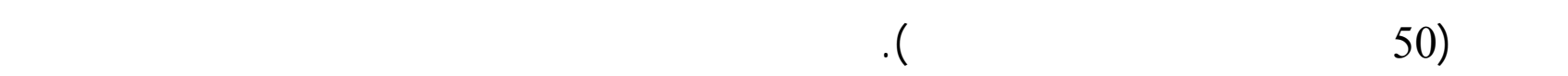

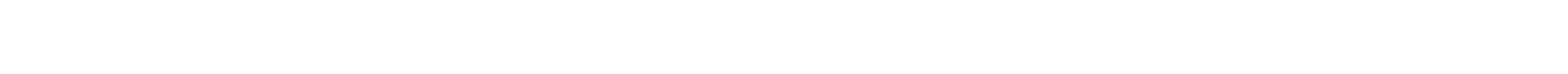

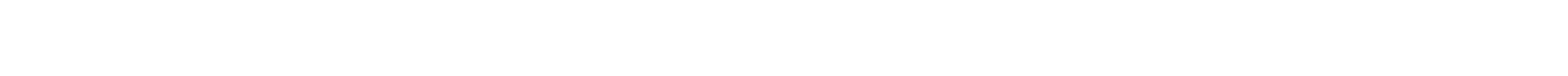

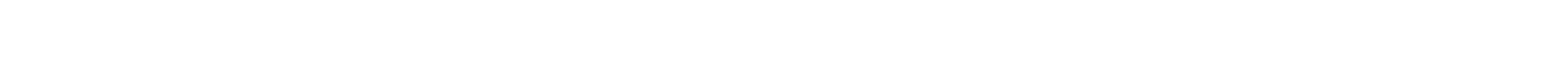

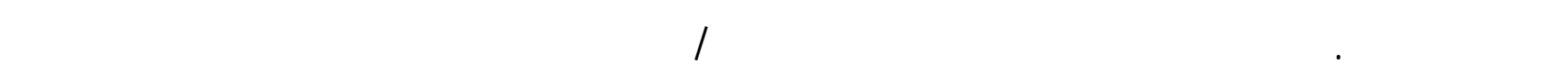

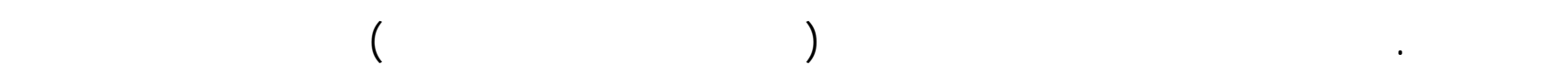

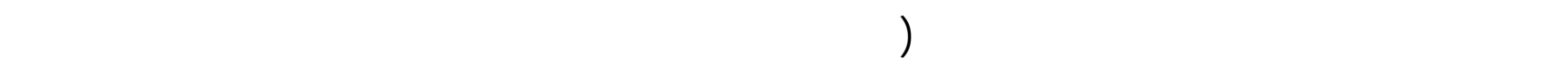
الثالث مع مجموعة اللسيطرة فقدظهر الانخفاض معنويا).

\section{INTRODUCTION}

Pregnancy is a physiological process associated with marked structural and functional changes in the female reproductive system. All other systems of the body are affected by the pregnancy to various degrees. Maternal changes in the endocrine, nervous, renal, cardiovascular and respiratory system were studied during pregnancy but the changes which occur in the liver functions are poorly studied and the literature in this field is relatively less provided compared with other systems (Mackillop and Williams, 2009).

The liver has a central and critical biochemical roles in the metabolism, digestion, detoxification and elimination of substances from the body (Widmaier et al., 2006). Liver functions are assessed by measuring the concentration of substances produced by hepatocytes or by measuring the serum content of substances released from these cells as a result of damage and assessing the capability of liver to perform metabolic functions like detoxification, conjugation (Rosenthal, 1997). Liver function tests are used for detecting liver disease occurance, and the site of this disease and allow follow up of liver disease progression (Dufour et al., 2000). Serum aminotransferase assays are the most common laboratory tests for detection of liver diseases. These enzymes include aspartate aminotransferase (AST) and alanine aminotransferase (ALT). They are excellent markers of hepatocellulare injury (Kim et al., 2004). AST is found primarily in the heart, liver, skeletal muscles, kidney, brain, pancreas, lung leukocytes and red blood cells (Pratt and Kaplan, 2000), while ALT is found primarily in the liver and kidney with lesser amount in the heart and skeletal muscles (Mandell et al., 2000); (Sherman, 1999). ALT is thought to be more specific for hepatic injury because it is present mainly in the cytosol of the liver cells and in low concentration elsewhere (Gibony, 2005). While AST is both cytosolic (20\% of total activity) and mitochondria ( $80 \%$ of total activity) it is less sensitive and specific for the liver (Giannini, 2005). AST and ALT participate in gluconeogenesis by catalyzing the reversible transfer of alpha amino groups of amino acid aspartic acid and alanine to the alphaketoglutaric lead to produce oxaloacetic acid (AST) and pyruvic acid (ALT) (Limdi and Hyde, 2003). 
Alkaline phosphatase (ALP) comprises a group of enzymes that catalyze the hydrolysis of phosphate esters in alkaline environment, generating an organic radical and inorganic phosphate (Wiwanitkit, 2001). It is found throughout the body in a varity of isoenzyme unique to the tissue of origin. Highest concentrations are in liver and bone, but the enzyme is present in lesser amount in placenta, kidney, intestine and leukocyte (Corathers, 2006). An elevated level of serum ALP may indicate an abnormal liver or bone functions (Foreman et al., 2005). Bilirubin is the final product of heme degradation (Porter and Dennis, 2002). The human body produces about $4 \mathrm{gm}$ Bilirubin $/ \mathrm{kg} /$ day from metabolism of heme. Hemoglobin $(\mathrm{Hb})$ is broken by macrophage in the tissues to biliverdin then to bilirubin the globin part is degraded ultimately to amino acid (a.a) and iron complex with transferrin. Bilirubin is transported, bound to albumin, then enter to the liver and is modified to excretable conjugated form (Campbell, 2006); (Dennery et al., 2001). Bilirubin is produced within reticuloendothelial system and released in unconjugated form which enter into the liver, then converted to conjugated form bilirubin mono and diglucuronid by enzyme UDP glucuronyl transferase (Foreman et al., 2005). Because unconjugated bilirubin is toxic and insoluble it must be glucurinided before excreted in the bile (Baranano et al., 2002).

\section{SUBJECTS, MATERIALS AND METHODS}

This study represents as a case-control study. The total number of subjects included in this study is 200 subjects, they are divided into two groups:

\section{A. Pregnant group}

One hundred and fifty apparently healthy pregnant women; their ages between (16-41) years with a mean of (24.15) years who attended Al-Khansaa Hospital and Al-Quds Health Center as an out patients for their routine antenatal care referred by gynecologist. This group was subdivided into three subgroups according to their gestational period of pregnancy:

1. Fifty pregnant women in late $1^{\text {st }}$ trimester of pregnancy (10-13 weeks).

2. Fifty pregnant women in late $2^{\text {nd }}$ trimester of pregnancy (23-26 weeks).

3. Fifty pregnant women in late $3^{\text {rd }}$ trimester of pregnancy (36-39 weeks).

\section{B. Control group}

Fifty apparently healthy non pregnant women were consider as a control group; their ages between (17-40) years with a mean of (26.26) years. A complete history of both groups of women was obtained including name, age, weight, high, occupation, gravida, parity, history of previous pregnancies, family history, and drug intake. Those with a history of cardiac, renal or hepatic disease, hypertension, diabetes mellitus, obesity, and drug intake were excluded from the two groups. Approximately $5 \mathrm{ml}$ of venous blood was obtained from each woman of control and pregnant groups by anticubital vein puncture and stressful vein puncture was avoided. All subjects in the study were instructed to have an overnight fasting between 12-14 hours. The samples were transferred immediately into plain plastic tubes and were placed in a $37^{\circ} \mathrm{C}$ water bath for 10 minutes and centrifuged at $3000 \mathrm{rpm}$ for 15 minutes to ensure complete separation of serum. Serum was used for measurement serum liver enzymes activity which included (AST, ALT and ALP) and bilirubin (total, direct and indirect). Serum AST and ALT activity were measured colorimetrically according to the 
method of (Reitman and Frankel, 1957); using kit supplied by Randox/ UK. Serum ALP activity was measured colorimetrically according to the method of (Kind and King, 1954); using kit supplied by BioMerieux/ France. Serum total bilirubin (TB) and direct bilirubin (DB) were measured colorimetrically according to (Walters and Gerarde, 1970); using kit supplied by Biolabo SA/ France. Indirect bilirubin (IB) can calculated by the following equation:

Indirect Bilirubin $(\mu \mathrm{mol} / \mathrm{L})=$ Total Bilirubin - Direct Bilirubin

\section{STATISTICAL ANALYSIS}

Data were analysed using unpaired t-test. The results were expressed as mean \pm standard deviation (SD). $\mathrm{P} \leq 0.05, \mathrm{P} \leq 0.01, \mathrm{P} \leq 0.001$ were considered as statistically significant (Armitage and Berry, 1985).

\section{RESULTS AND DISCUSSION}

According to comparison of serum aminotransferase (AST and ALT) between pregnant women in the $1^{\text {st }}, 2^{\text {nd }}$ and $3^{\text {rd }}$ trimesters and control group, a non significant $(\mathrm{P}>0.05)$ difference in the mean value of serum AST activity was observed in pregnant women at $1^{\text {st }}$, $2^{\text {nd }}$ and $3^{\text {rd }}$ trimesters $(8.90 \pm 3.72 \mathrm{U} / \mathrm{L}),(8.54 \pm 3.78 \mathrm{U} / \mathrm{L}),(8.01 \pm 3.54 \mathrm{U} / \mathrm{L})$ respectively as compared with control group $(9.38 \pm 4.42 \mathrm{U} / \mathrm{L})$ as in tables $(1,2,3)$. These results of our study agree with Benjaminov and Healthcote (2004), show that there is non significant change in the AST during pregnancy. Carter (1990), shows that the serum AST activity levels do not change during pregnancy or remain within the normal limits established in nonpregnant women.

However, there was a slight difference but statistically not significant $(\mathrm{P}>0.05)$ in serum ALT activity in pregnant women at $1^{\text {st }}$ trimester $(8.43 \pm 2.31 \mathrm{U} / \mathrm{L})$ in comparison with control group $(8.35 \pm 3.06 \mathrm{U} / \mathrm{L})$ as in table $(1)$, while a significant $(\mathrm{P} \leq 0.001)$ decrease in the mean value of serum ALT activity was observed in pregnant women at $2^{\text {nd }}$ and $3^{\text {rd }}$ trimesters $(6.44 \pm 2.03 \mathrm{U} / \mathrm{L}),(5.28 \pm 1.47 \mathrm{U} / \mathrm{L})$ respectively as compared with control group $(8.35 \pm 3.06$ $\mathrm{U} / \mathrm{L})$ as in tables $(2,3)$. This reduction in ALT especially in the late pregnancy may be attributed to hemodilution which occurs during pregnancy secondary to the increase in circulatory volume. These results come in agreement with Rahman and Wendon (2002); Huy (2005) showed that ALT activity is low in pregnants compared with non pregnants.

The comparison of serum alkaline phosphatase ALP activity between pregnant women in the $1^{\text {st }}$ trimester and control group, revealed a slight difference but not statistically significant $(\mathrm{P}>0.05)$ of serum ALP activity in pregnant women at $1^{\text {st }}$ trimester $(68.74 \pm 17.01$ $\mathrm{U} / \mathrm{L})$ in comparison with control group $(67.44 \pm 14.19 \mathrm{U} / \mathrm{L})$ as in table $(1)$, while there was a significant increase in pregnant women at $2^{\text {nd }}$ and $3^{\text {rd }}$ trimesters $(80.15 \pm 30.81 \mathrm{U} / \mathrm{L})$, $(151.51 \pm 81.66 \mathrm{U} / \mathrm{L})$ respectively as compared with control group $(67.44 \pm 14.19 \mathrm{U} / \mathrm{L})$ at $(\mathrm{P} \leq 0.01)$ and $(\mathrm{P} \leq 0.001)$ respectively as in tables $(2,3)$. This elevation at these pregnancy trimesters may be attributed to the placental ALP (PLALP) and bone ALP origin. Other studies also indicated that there is a pregnancy -dependent increase in total ALP activity in serum might reflect increase in both PLALP and bone ALP Sembaj et al., (1999); Doshi and Zucker (2003); Carter (1990). In the last trimester, this increase may be up to four time normal Knopp et al., (1985); Järnfelt-Samsioe et al., (1986). These findings agrees with Bacq et al., (1996), who found that changes in liver function test (LFT) values during 
normal pregnancy have not clearly established except for increase in serum ALP levels . Mitra and Pralhad (2008), indicate that several physiologic changes occur during pregnancy and could pose difficulty in evaluating hepatobiliary function because they may be misinterpreted as pathological; for example, serum alkaline phosphatase levels may be elevated three to four folds due to placental production, so PLALP is used as useful indicator for placental function. Low PLALP is associated with delay uterine growth Sembaj et al., (1999).

For AST/ALT ratio the mean value shows a non significant $(\mathrm{P}>0.05)$ difference in pregnant women at $1^{\text {st }}$ trimester $(1.12 \pm 0.54)$ as compared with control group $(1.21 \pm 0.66)$ as in table (1), also in the $2^{\text {nd }}$ trimester shows a non significant $(\mathrm{P}>0.05)$ difference $(1.39 \pm 0.70)$ as compared with control group $(1.21 \pm 0.66)$ as in table $(2)$, in addition, the mean value of AST/ALT ratio shows a significant $(\mathrm{P} \leq 0.01)$ elevation in pregnant women at $3^{\text {rd }}$ trimester $(1.58 \pm 0.71)$ as compared with control group (1.21 \pm 0.66$)$ as in table (3).

A comparison of serum bilirubin between pregnant women in the $1^{\text {st }}$ trimester and control group show a non significant $(\mathrm{P}>0.05)$ difference in the mean value of serum total bilirubin, direct bilirubin and indirect bilirubin was observed in pregnant women in the $1^{\text {st }}$ trimester $(7.69 \pm 2.88 \mu \mathrm{mol} / \mathrm{L}),(1.76 \pm 0.93 \mu \mathrm{mol} / \mathrm{L})$ and $(5.93 \pm 2.84 \mu \mathrm{mol} / \mathrm{L})$ respectively compared with control group $(7.97 \pm 2.77 \mu \mathrm{mol} / \mathrm{L}),(1.78 \pm 1.27 \mu \mathrm{mol} / \mathrm{L})$ and $(6.18 \pm 2.42$ $\mu \mathrm{mol} / \mathrm{L})$ respectively as in table (1).

Regarding the comparison of serum bilirubin between pregnant women in the $2^{\text {nd }}$ trimester and control group, show a non significant $(\mathrm{P}>0.05)$ difference in the mean value of serum total bilirubin, direct bilirubin and indirect bilirubin was observed in pregnant women in the $2^{\text {nd }}$ trimester $(7.05 \pm 3.21 \mu \mathrm{mol} / \mathrm{L}),(1.68 \pm 0.71 \mu \mathrm{mol} / \mathrm{L})$ and $(5.37 \pm 3.44 \mu \mathrm{mol} / \mathrm{L})$ respectively compared with control group $(7.97 \pm 2.77 \mu \mathrm{mol} / \mathrm{L}),(1.78 \pm 1.27 \mu \mathrm{mol} / \mathrm{L})$ and $(6.18 \pm 2.42 \mu \mathrm{mol} / \mathrm{L})$ respectively as in table (2).

A comparison of serum bilirubin between pregnant women in the $3^{\text {rd }}$ trimester and control group show that the reduction in the mean value of serum total bilirubin in pregnant women at $3^{\text {rd }}$ trimester is statistically significant $(6.87 \pm 2.44 \mu \mathrm{mol} / \mathrm{L})$ as compared with control group $(7.97 \pm 2.77 \mu \mathrm{mol} / \mathrm{L})$ at $(\mathrm{P} \leq 0.05)$. While a non significant $(\mathrm{P}>0.05)$ difference in the mean value of serum direct and indirect bilirubin was observed in pregnant women at $3^{\text {rd }}$ trimester $(1.62 \pm 1.03 \mu \mathrm{mol} / \mathrm{L})$ and $(5.24 \pm 2.73 \mu \mathrm{mol} / \mathrm{L})$ respectively as compared with control group $(1.78 \pm 1.27 \mu \mathrm{mol} / \mathrm{L})$ and $(6.18 \pm 2.42 \mu \mathrm{mol} / \mathrm{L})$ respectively as in table (3). The reduction of serum total bilirubin in $3^{\text {rd }}$ trimester of pregnancy may be due to hemodilution secondary to pregnancy Bacq et al., (1996).

Our results are in agree with Bacq et al., (1996); Järnfelt-Samsioe et al., (1986); Knopp et al., (1985) indicated that total bilirubin concentration are decreased during all three trimesters of pregnancy.

In conclusion, pregnancy is a major factor that contributes for the significant elevation of serum ALP activity and a significant reduction of serum ALT activity while the rest of parameters including bilirubin and AST activity shows a non significant differences. 
Table 1: Comparison of liver function tests between pregnant women in the $1^{\text {st }}$ trimester and control group.

\begin{tabular}{|c|c|c|c|c|c|}
\hline \multirow[t]{2}{*}{ Parameters } & \multicolumn{2}{|c|}{$\begin{array}{c}1^{\text {st }} \text { trimester } \\
(n=50)\end{array}$} & \multicolumn{2}{|c|}{$\begin{array}{c}\text { Control group } \\
(n=50)\end{array}$} & \multirow[t]{2}{*}{$\begin{array}{c}\text { P- } \\
\text { Value }\end{array}$} \\
\hline & Mean \pm SD & Range & Mean \pm SD & Range & \\
\hline AST (U/L) & $8.9 \pm 3.72$ & $2.0-19.0$ & $9.38 \pm 4.42$ & $3-17$ & NS \\
\hline $\operatorname{ALT}(\mathrm{U} / \mathrm{L})$ & $8.43 \pm 2.31$ & $4.0-13.0$ & $8.35 \pm 3.06$ & $4-15$ & $\mathrm{NS}$ \\
\hline $\operatorname{ALP}(\mathrm{U} / \mathrm{L})$ & $68.74 \pm 17.01$ & $42.28-109.49$ & $67.44 \pm 14.19$ & $44.63-89.87$ & NS \\
\hline AST/ALT & $1.12 \pm 0.54$ & $0.33-2.37$ & $1.21 \pm 0.66$ & $0.37-3.37$ & NS \\
\hline $\begin{array}{c}\text { Total bilirubin } \\
(\mu \mathrm{mol} / \mathrm{L})\end{array}$ & $7.69 \pm 2.88$ & $2.73-11.89$ & $7.97 \pm 2.77$ & $3.9-14.23$ & $\mathrm{NS}$ \\
\hline $\begin{array}{c}\text { Direct bilirubin } \\
(\mu \mathrm{mol} / \mathrm{L})\end{array}$ & $1.76 \pm 0.93$ & $0.39-4.48$ & $1.78 \pm 1.27$ & $0.39-4.48$ & NS \\
\hline $\begin{array}{c}\text { In direct } \\
\text { bilirubin }(\mu \mathrm{mol} / \mathrm{L})\end{array}$ & $5.93 \pm 2.84$ & $0.97-10.92$ & $6.18 \pm 2.42$ & $0.78-10.53$ & NS \\
\hline
\end{tabular}

NS $=$ Not significant.

Table 2: Comparison of liver function tests between pregnant women in the $2^{\text {nd }}$ trimester and control group.

\begin{tabular}{|c|c|c|c|c|c|}
\hline \multirow[t]{2}{*}{ Parameters } & \multicolumn{2}{|c|}{$\begin{array}{c}2^{\text {nd }} \text { trimester } \\
(n=50)\end{array}$} & \multicolumn{2}{|c|}{$\begin{array}{c}\text { Control group } \\
(\mathbf{n}=\mathbf{5 0})\end{array}$} & \multirow[t]{2}{*}{ P-Value } \\
\hline & Mean \pm SD & Range & Mean \pm SD & Range & \\
\hline AST (U/L) & $8.54 \pm 3.78$ & $3.0-16.0$ & $9.38 \pm 4.42$ & $3-17$ & NS \\
\hline ALT (U/L) & $6.44 \pm 2.03$ & $4.0-11.0$ & $8.35 \pm 3.06$ & $4-15$ & $\leq 0.001$ \\
\hline $\operatorname{ALP}(\mathbf{U} / \mathbf{L})$ & $80.15 \pm 30.81$ & $45.12-201.0$ & $67.44 \pm 14.19$ & $44.63-89.87$ & $\leq 0.01$ \\
\hline AST/ALT & $1.39 \pm 0.70$ & $0.57-3.37$ & $1.21 \pm 0.66$ & $0.37-3.37$ & NS \\
\hline $\begin{array}{c}\text { Total bilirubin } \\
(\mu \mathrm{mol} / \mathrm{L})\end{array}$ & $7.05 \pm 3.21$ & $2.92-13.26$ & $7.97 \pm 2.77$ & $3.9-14.23$ & NS \\
\hline $\begin{array}{c}\text { Direct bilirubin } \\
(\mu \mathrm{mol} / \mathrm{L})\end{array}$ & $1.68 \pm 0.71$ & $0.58-3.12$ & $1.78 \pm 1.27$ & $0.39-4.48$ & $\mathrm{NS}$ \\
\hline $\begin{array}{c}\text { In direct } \\
\text { bilirubin }(\mu \mathrm{mol} / \mathrm{L})\end{array}$ & $5.37 \pm 3.44$ & $0.39-12.09$ & $6.18 \pm 2.42$ & $0.78-10.53$ & $\mathrm{NS}$ \\
\hline
\end{tabular}

$\mathrm{NS}=$ Not significant. 
Table 3: Comparison of liver function tests between pregnant women in the $3^{\text {rd }}$ trimester and control group.

\begin{tabular}{|c|c|c|c|c|c|}
\hline \multirow[t]{2}{*}{ Parameters } & \multicolumn{2}{|c|}{$\begin{array}{c}3^{\text {rd }} \text { trimester } \\
(n=50)\end{array}$} & \multicolumn{2}{|c|}{$\begin{array}{c}\text { Control group } \\
(\mathrm{n}=50)\end{array}$} & \multirow[t]{2}{*}{ P-Value } \\
\hline & Mean \pm SD & Range & Mean \pm SD & Range & \\
\hline AST (U/L) & $8.01 \pm 3.54$ & $3.0-16.0$ & $9.38 \pm 4.42$ & $3-17$ & NS \\
\hline ALT (U/L) & $5.28 \pm 1.47$ & $4.0-10.0$ & $8.35 \pm 3.06$ & $4-15$ & $\leq 0.001$ \\
\hline $\operatorname{ALP}(\mathbf{U} / \mathbf{L})$ & $151.51 \pm 81.66$ & $48.57-357.49$ & $67.44 \pm 14.19$ & $44.63-89.87$ & $\leq 0.001$ \\
\hline AST/ALT & $1.58 \pm 0.71$ & $0.42-3.5$ & $1.21 \pm 0.66$ & $0.37-3.37$ & $\leq 0.01$ \\
\hline $\begin{array}{l}\text { Total bilirubin } \\
(\mu \mathrm{mol} / \mathrm{L})\end{array}$ & $6.87 \pm 2.44$ & $2.73-13.65$ & $7.97 \pm 2.77$ & $3.9-14.23$ & $\leq 0.05$ \\
\hline $\begin{array}{c}\text { Direct bilirubin } \\
(\mu \mathrm{mol} / \mathrm{L})\end{array}$ & $1.62 \pm 1.03$ & $0.36-3.9$ & $1.78 \pm 1.27$ & $0.39-4.48$ & NS \\
\hline $\begin{array}{c}\text { In direct } \\
\text { bilirubin }(\mu \mathrm{mol} / \mathrm{L})\end{array}$ & $5.24 \pm 2.73$ & $0.58-12.28$ & $6.18 \pm 2.42$ & $0.78-10.53$ & NS \\
\hline
\end{tabular}

$\mathrm{NS}=$ Not significant.

\section{REFERENCES}

Armitage, P.; Berry, G. (1985). "Statistical Methods in Medical Research". 2nd edn., Blackwell, Oxford, London, UK, pp. 60-75.

Bacq, Y.; Zarka, O.; Brechot, J.F. (1996). Liver function tests in normal pregnancy a prospective study of 103 pregnant women and 103 matched controls. Hepatology, 23: $1030-1034$.

Baranano, D.E.; Rao, M.; Ferris, C.D.; Snyder, S.H. (2002). Biliverdine reductase: a major physiological cytoprotectant. Proc. Natl. Acad. Sci., 99 (25), 16093-16098.

Benjaminov, F.S.; Healthcote, J. (2004). Liver disease in pregnancy. Am. J. Gastroenterol., 99, 2479-88.

Campbell, L. (2006). Liver: metabolic function. Ansth. Intens Care Med., 7 (2), 51-54.

Carter, J. (1990). Liver function in normal pregnancy. Aust. NZ. J. Obstet. Gynaecol., 30, 296-302.

Corathers, S.D. (2006). Focus on diagnosis, the alkaline phosphatase level: nuances of a family test. Pediatric in Review, 27, 382-384.

Dennery, P.A.; Seidman, D.S.; Stevenson, D.K. (2001). Neonatal Hyperbilirubinemia. N. Engl. J. Med., 344 (8),581-590.

Doshi, S.; Zucker, S.D. (2003). Liver emergency during pregnancy. Gastroenterol. Clin. N. Am., 32, 1213-27.

Dufour, R.; Lott, J.; Nolte, F.; Greth, D.; Koff, R.; Seef, L. (2000). Dignosis and monitoring of hepatic injury. performance characteristic of laboratory test. Clin. Chem., 46, 2027-2068.

Foreman, J.E.; Blizard, D.A.; Gerhard, G.; Mack, H.A.; Lang, D.H.; Van Nimwegen, K.L. (2005). Serum alkaline phosphatase activity is regulate by a chromosomal region the containing alkaline phosphatase 2 gene (ALP2) in C57BL/2J mice. Physiological Genomics, 23,295-303. 
Giannini, E.G.; Testa, R.; Savarino, V. (2005). liver enzyme alteration: guide for clinicians. CAMJ, 172 (3), 367-391.

Gibony, P.T. (2005). Mildly elevated liver transaminase levels in asymptomatic patient. Am. Fam. Physician., 71, 1105-1110.

Huy, A.T. (2005). Abnormal laboratory results, biochemistry test in pregnancy. Aust. Prescr. 28, 98-101.

Järnfelt-Samsioe, A.; Eriksson, B.; Waldenström, J. (1986). Serum bile acids, gammaglutamyltransferase and routine liver tests in emetic and nonemetic pregnancies. Gynecol. Obstet. Invest., 21(4), 169-176.

Kim, H.C.; Nam, C.M.; Jee, K.H.; Oh, k.h.; Shuh, I.I. (2004). Normal serum aminotransferase concentration and risk of mortality from liver disease: Prospective cohort study. BMJ, 328-983.

Kind, P.; King, E. (1954). Estimation of plasma alkaline phosphatase by determination of hydrolysed phenol with aminoantipyrine. J. Clin. Pathol., 7, 322-326.

Knopp, R.H.; Bergelin, R.O.; Wahl, P.W. (1985). Clinical chemistry alterations in pregnancy and oral contraceptive use. Obstet. Gynecol., 66 (5), 682-690.

Limdi, J.K.; Hyde, G.M. (2003). Evaluation of abnormal liver function tests. Post Grad. Med., 79 (932), 307-312.

Mackillop, L.; Williams, C. (2009). Liver disease in pregnancy. Post grad. Med. J., 86, 160164.

Mandell, G.L.; Drazen, J.M.; Gill, G.N.; Grigger, RC.; Kokko, T.P.; Cecill, (2000). "Textbook of Medicine". 21 ed ., Saunders, Philadelphia, USA, pp. 775-80.

Mitra, A.K.; Pralhad, S. (2008). Liver disorders during pregnancy and their management. The antiseptic, 105 (4), 193-196.

Porter, M.L.; Dennis, B.L. (2002). Hyperbilirubinemia in the term newborn. Am. Fam. Physician., 65, 599-606.

Pratt, D.S.; Kaplan, M.M. (2000). Evaluation of abnormal liver enzyme result in asymptomatic patient S.N Engl. J. Med., 342, 1266-1271.

Rahman, T. M.; Wendon, J. (2002). Sever hepatic dysfunction in pregnancy. Q. J. Med., 95, 343-357.

Reitman, S.; Frankel, S. (1957). A colorimetric method for the determination of serum glutamic oxaloacetic and glutamic pyruvic transaminase. Am. J. Clin. Pathol., 28, 56-59.

Rosenthal, P. (1997). Assessing liver function and Hyperbilirubinemia in the newborn. Clin. Chem., 43(1), 228-234.

Sembaj, A.; Sanz, E.; Castro, I.; Gonzales, A.; Carriazo, C.; Barral, J.M. (1999). Alkaline phosphatase isoenzyme in plasma chagasic and healthy pregnant woman. J. Mem. Inst. Oswaldo. Cruz., 94(6), 785-786.

Sherman, K.E. (1999). Aminotransferase in clinical practice. Arch. Inter. Med., 151, 260-265.

Walters, M.; Gerarde, H. (1970). Determination of serum bilirubin. Micro. Chem. J., 15, 231-243.

Widmaier, E.P.; Raff, H.; Strang, K.T. (2006). "Vander's Human Physiology, the Mechanisms of Body Function". 10th ed., McGraw-Hill, pp. 575-583.

Wiwanitkit, V. (2001). High serum alkaline phosphatase levels, a study in 181Thia adult hospitalized patient. BMC Family practice, 2, 2. 